\title{
Biodegradation of Azo Dyes by Three Isolated Bacterial Strains: An Environmental Bioremedial Approach
}

\section{Maulin P Shah*}

Industrial Waste Water Research Laboratory, Applied and Environmental Microbiology Lab, Enviro Technology Limited (CETP), Gujarat, India

\begin{abstract}
The present study was conducted to investigate the decolorization and degradation of azo dyes using bacteria isolated from textile dye effluent. Three different bacterial species were isolated and the isolates were identified as Bacillus subtilis, Pseudomonas aeruginosa, and Psuedomonas putida. The bacterial inoculums were inoculated into flasks containing azo dyes $(500 \mathrm{mg} / \mathrm{l})$ with trace amounts of yeast extract, glucose and sucrose and then sterilized and incubated for 4 days. The decolourization was expressed in terms of percentage decolourization. Psuedomonas putida (95\%) was identified as the best decolourizer of Blue RR. Pseudomonas aeruginosa (93\%) was the best decolourizer of Black B. The best decolourizer of Red RR was Bacillus subtilis (91\%). Bacillus subtillis $(65 \%)$ highly decolourized the Yellow RR. Pseudomonas aeruginosa (70.58\%) was the best decolourizer of Navy Blue. The degradation product after decolorization was examined by thin layer chromatography and Fourier transformed infrared spectroscopy analysis.
\end{abstract}

Keywords: Black B; Red RR; Yellow RR; Pseudomonas; TLC; FTIR

\section{Introduction}

The degradation of the environment due to the discharge of polluting wastewater from industrial sources is a real problem in several countries. This situation is even worse in developing countries like India where little or no treatment is carried out before the discharge $[1,2]$. Dyeing and printing of textile manufacturing has been development with human civilization. Today these industries are the backbone of economy in many developed as well as developing countries. In India, it contributes to about $25 \%$ of total export earnings and providing employment to almost $1 / 4$ of the total labor force $[3,4]$. A considerable amount of waste water is generated having strong color, a large amount of suspended solids, a highly fluctuating $\mathrm{pH}$, salts, heavy metals, sulphides, chlorine, temperature and COD concentration [5]. The disposal of untreated textile wastewater is a serious threat to the environment. It accounts for $15-20 \%$ of total wastewater in the country [4]. The dyes are the most visible pollutant in the wastewater. About 3500 dyes are in practical use. Azo dyes contribute $84 \%$, of which sulphonated azo dyes predominate. About 10-15\% (128 tons/day globally) of the dyes are lost at various finishing steps of the printed cloths. Besides dyes, the wastewater contains acids/alkalis, common salt $(\mathrm{NaCl})$, heavy metals, sulphides, chlorine and mineral oils. As a result, the dye wastewaters are extremely toxic to both aquatic fauna and flora, crop plants, including human beings [6]. Traditionally, the dye effluents are treated by physical, chemical and biological methods [7-11]. In spite of the many steps taken to maintain and improve the quality of surface and groundwater, the quantities of wastewater generated by these industries continue to increase and municipalities and industries are confronted with an urgent need to develop safe and feasible alternative practices for wastewater management. Treatment of dye-contaminated wastewater discharged from the textile and other dye-stuff industries is necessary to prevent contamination of soil and surface and ground water. Currently, there are several physicochemical and biological methods for the removal of dyes from effluents [12-21]. Among these, biotechnological approaches are receiving increased attention worldwide as environmental-friendly methods that are becoming increasingly efficient and cost-effective for the remediation of dye-contaminated wastewater [21,22]. Many biotreatment systems rely on the use of sludge as an inoculum to initiate the dye degradation process $[23,24]$. While generally effective, it is nonetheless important to assure complete mineralization and detoxification for use as a reliable treatment method. Azo dyes and their degradation intermediates vary in their recalcitrance to biodegradation due to their complex structures and xenobiotic nature and in some cases are both mutagenic and carcinogenic [25-32]. Furthermore, azo-dye degrading microbial communities are sensitive to high concentrations of salts that are used in the dye process [33,34]. This can limit growth and activity of the degrader bacteria such that the process treatment times become impractical. With the discovery and isolation of very efficient, salt-tolerant azo-dye degrading bacteria, bioaugmentation of biotreatment systems with specific microbial strains has now become an effective strategy to improve wastewater treatment systems and to enhance the bioremediation of azo dyes [35-39]. Although many microorganisms can degrade azo dyes [40-47] relatively few microbial species and strains have emerged as candidates for use in bioaugmentation [22,41,48-51]. Before individual isolates can be recommended, comprehensive research is required to understand the role of individual microorganisms and their interactions with other microflora $[30,52,53]$. In this paper, various types of azo dye degrading microorganisms and their potential for bioaugmentation are discussed.

\section{Materials and Methods}

\section{Sample collection and preservation}

The dye house effluent was collected from a small dyeing industry from where the colored effluent pass was used as the parent source of inoculums in the present study. The sample was collected in a brown

*Corresponding author: Maulin P Shah, Industrial Waste Water Research Laboratory, Applied and Environmental Microbiology Lab, Enviro Technology Limited (CETP), Plot No: 2413/2414, GIDC, Ankleshwar- 393 002, Gujarat, India, Tel: +91-90 999 65504; E-mail: shahmp@uniphos.com

Received April 03, 2014; Accepted July 23, 2014; Published July 30, 2014

Citation: Shah MP (2014) Biodegradation of Azo Dyes by Three Isolated Bacterial Strains: An Environmental Bioremedial Approach. J Microbial Biochem Technol S3: 007. doi:10.4172/1948-5948.S3-007

Copyright: @ 2014 Shah MP. This is an open-access article distributed under the terms of the Creative Commons Attribution License, which permits unrestricted use, distribution, and reproduction in any medium, provided the original author and source are credited 
bottle. Prior to the collection the sample bottle was rinsed thoroughly with the sample water. Then the sample was brought to the laboratory as early as possible and was subjected for various physico-chemical and microbiological studies.

\section{Dyes and media}

The common name of the reactive azo dyes viz. Blue RR, Black B, Red RR, Yellow RR and Navy blue used for the biodecolorization studies were generous gift from the dyeing industry situated at Ankleshwar, Gujarat, India. All other chemicals were analytical grade. The Mineral Salt Medium (MSM) of $\mathrm{pH} 7.0$ contains $\left(\mathrm{gm} / \mathrm{L}^{-1}\right)$ the following composition; $\mathrm{NaCl}(1.0), \mathrm{CaCl}_{2} .2 \mathrm{H}_{2} \mathrm{O}(0.1), \mathrm{MgSO}_{4} .7 \mathrm{H}_{2} \mathrm{O}$ (0.5), $\mathrm{KH}_{2} \mathrm{PO}_{4}(1.0)$ and $\mathrm{Na}_{2} \mathrm{HPO}_{4}(1.0)$.

\section{Isolation, identification and maintenance of dye decolorizing bacteria}

Pour plate technique was used for the isolation of dye decolorizing bacteria. Well grown bacterial colonies were picked and further purified by streaking. The isolated strains were maintained on Nutrient agar slants and stored at $4^{\circ} \mathrm{C}$. Identification of the bacterial isolates was carried out by the routine bacteriological methods i.e., By the colony morphology, preliminary tests like Gram staining, capsule staining, endospore staining, motility, catalase and oxidase, plating on selective medias and performing biochemical tests.

\section{Screening of bacterial isolates for textile dye degradation}

Inoculum preparation: Isolates were individually tested for their growth and decolorization ability on Nutrient agar medium containing $100 \mathrm{ppm}$ of each dye. All the dyes were prepared separately and each of the cultures was tested against a single dye. The plates were incubated at $37 \pm 2{ }^{\circ} \mathrm{C}$ till zone formation. Based on the growth on the nutrient agar medium, secondary screening was performed with the same procedure on solid MSM medium incorporated with $10 \mathrm{ppm}$ of different dyes.

Dye decolorization experiments: Dye decolorization experiments were carried out in $100 \mathrm{ml}$ flasks containing $50 \mathrm{ml}$ of Blue RR, Black B, Red RR, Yellow RR and Navy blue dyes $(500 \mathrm{mg} / \mathrm{l})$, traces of yeast extract, sucrose and glucose. The $\mathrm{pH}$ was adjusted to $7 \pm 0.2$ using sodium hydroxide and hydrochloric acid solution. Then, the flasks were autoclaved at $121^{\circ} \mathrm{C}$ for 15 minutes. The autoclaved flasks were inoculated with $5 \mathrm{ml}$ of bacterial inoculums of each isolates. The flasks were kept in shaker and incubated at $37^{\circ} \mathrm{C} \pm 2$ for 4 days. Samples were drawn at 24 hours intervals for observation. $10 \mathrm{ml}$ of the dye solution was filtered and centrifuged at $8000 \mathrm{rpm}$ for 20 minutes. Decolorization was assessed by measuring absorbance of the supernatant with the help of spectrophotometer at wavelength maxima $(\lambda \mathrm{m})$ of respective dye.

Decolorization assay: Decolorization assay was measured in the terms of percentage decolorization using UV-Spectrophotometer. The percentage decolorization was calculated from the following equation,

\section{$\%$ Decolorization $=\left(\right.$ Initial OD-Final OD $\left.{ }^{\star} 100\right) /$ Initial OD}

\section{Acclimatization study}

The acclimatization was done gradually exposing the isolates to increasing concentrations of different mixed azo dyes viz. Blue RR, Black B, Red RR, Yellow RR and Navy blue. The stock mixture contained $300 \mathrm{mg}^{-1}$ of each dye. Cultures which were obtained from secondary screening were utilized for the study. The set-up contained liquid MSM composed of $100 \mathrm{ppm}$ of mixed dye. When decolorization occurred, an additional $250 \mathrm{ppm}$ of dye was added to the same flask. Likewise the dye was added in increasing concentration to the decolorized medium. Consecutive cycles of dye decolorization were studied by the repeated additions of mixed dye to the medium.

\section{Analysis of biodegradable product}

The degraded product was extracted from the efficient strain. Cells were centrifuged and supernatant was extracted with the equal volume of ethyl acetate and then dried over anhydrous sodium sulphate. The residue was dissolved in a small amount of methanol and this was utilized for a TLC test. The developing solvent systems used were ethyl acetate: hexane $(2: 3, \mathrm{v} / \mathrm{v})$ for biotransformed intermediates/products and ethyl acetate: methanol $(7: 3, \mathrm{v} / \mathrm{v})$ for residual dye. The bands of aromatic compounds were observed under UV light $(365 \mathrm{~nm})$ and other bands were observed by exposing the plates to iodine vapor in an iodine chamber. Dry pallets were utilized for FTIR spectral analysis.

\section{Results and Discussion}

In past, Ankleshwar has been identified as one of the most polluted cities in India. The grave pollution situation that exists in and around Ankleshwar due to the textile industries has been extensively studied. Further, increasing trend of requirement and productivity of dyes and dye intermediates is associated with the anticipated generation of wastes, both liquid and solid in future. Many of the South Asian countries are experiencing severe environmental problems due to rapid industrialization. This phenomenon is very common where the polluting industries like textile dyeing, leather tanning, paper and pulp processing, sugar manufacturing etc. thrive as clusters. The effluent discharged by these industries leads to serious pollution of surface water sources, ground water, soils and ultimately affects the livelihood of the poor. Throughout India, there is a grave concern and constant attention given to the treatment of industrial effluents from textile and dye manufacturing units. Several researchers have demonstrated the possibility of utilizing microorganisms for biotreatment of textile wastewater. In India, most textile units are scattered and/or operated from private homes. Therefore, it is necessary to collect and treat the waste in common effluent treatment plants. Biological methods are simple to use and the cost of operation is low.

\section{Acclimatization study}

The acclimatization was done by gradually exposing the selected 30 isolates (obtained from secondary screening) in increasing concentrations of dye. Most of the dyeing unit in and around Ankleshwar region utilizing reactive dyes for dyeing fabrics. Thus our microbe have significant potential for decolorization of reactive textile dyes and are an important and promising material for the removal of dyes from textile effluents. Consecutive cycles of dye decolorization were studied by the repeated additions of mixed dye to the medium. Since waste of textile industries consist of mixture of various dyes, the ability of different isolates to decolorize the mixed textile dyes was studied. All the decolorization experiments were carried out under shaking conditions. Of the total isolates, the three most efficient strains were obtained through acclimatization capable of decolorizing 3000 ppm of mixed dye within 10 days of incubation. Biodegradation of commercially available textile dyes namely Blue RR, Black B, Red RR and Yellow RR, Navy Blue were studied against three bacterial isolates which have been isolated from the dye effluent sample by Pour plate method and percentage decolorization was shown in the Figures 3-7 accompanying the results. Based on preliminary tests, plating on selective media and biochemical tests, they were identified as Bacillus sp., Psuedomonas putida and Pseudomonas aeruginosa. Olukanni 


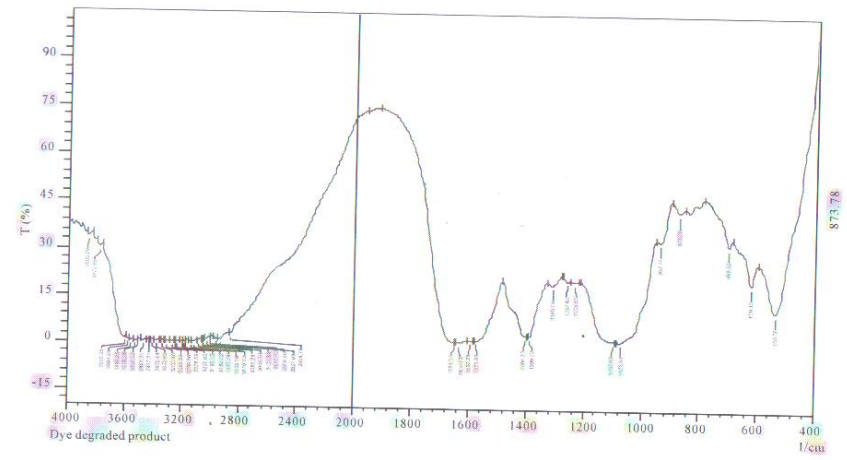

Figure 1: FTIR spectrum of control mixed dye.

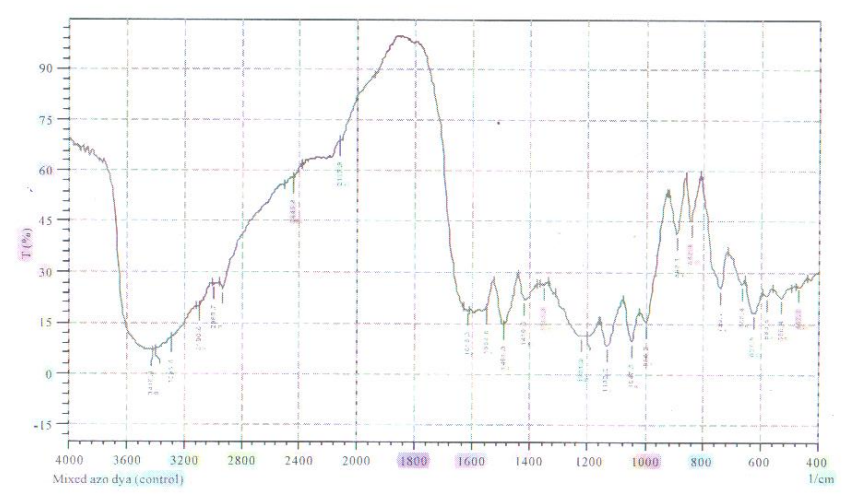

Figure 2: FTIR spectrum of degraded product.

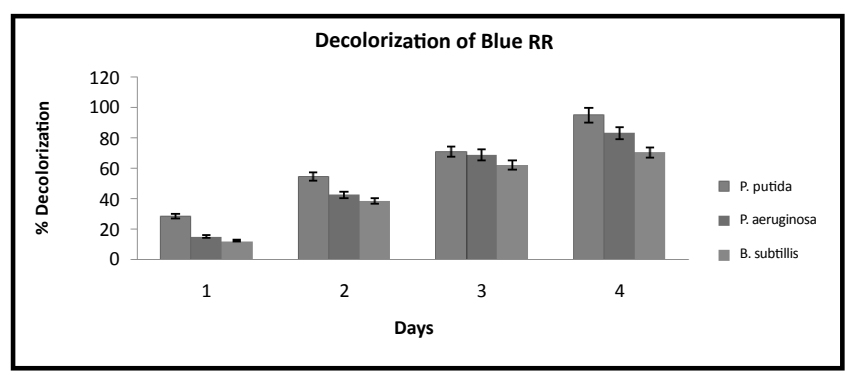

Figure 3: Decolorization of Blue RR.

et al. [54] isolated eighteen textile effluent adapted bacterial isolates belonging to the genera, Bacillus, Acinetobacter, Staphylococcus, Legionella and Pseudomonas were investigated for the potential of textile effluent adapted bacteria in decolourizing it. Bacillus and Legionella were found to have use in effluent treatment. Ajibola et al. [55] checked the ability of Staphylococcus aureus, Bacterioides fragilis, Bacillus subtilis, Bacillus cereus, Clostridium perifringens, Escherichia coli and Pepto streptococcus sp. to reduce and stabilize textile effluents containing predominantly Indigo Blue. In the present study, bacterial dye decolourization was studied using spectroscopic analysis. The bacterial inoculums were inoculated into the flasks containing azo dyes with trace amounts of yeast extract, glucose and sucrose and incubated for 4 days. The decolourization was expressed in terms of percentage decolourization. Psuedomonas putida (95\%) was identified as the best decolourizer of Blue RR. Pseduomonas aeruginosa (93\%) was the best decolourizer of Black B. The best decolourizer of Red RR was Bacillus subtilis (91\%). Bacillus subtillis best decolorizes Yello RR (65\%). Pseudomonas aeruginosa was the best decolorizer of navy blue (70.58\%). The decolourization of textile reactive azo dyes by Clostridium biofermentans isolated from a contaminated site was studied under aerobic conditions. Clostridium biofermentans decolourized the dyes Reactive red 3B-A, Reactive black 5, and Reactive yellow 3B-A, by over $90 \%$ after 36 hours post-inoculation spectrophotometric analyses of the reactive dyes showed no distinct peak indicating aromatic amines. The results suggested that Clostridium biofermentans was a suitable bacterium for the biological processing of dye-contaminating waste water [56]. Under anaerobic conditions, the decolourization of many azo dyes takes place via reduction of the azo bond for both aerobic as well as facultative anaerobic bacteria [57].

In this study, after inoculation of isolated bacterial consortium in textile dye effluent, the color changed from black to light brown. The $\mathrm{pH}$ was brought from 9.5 to 6.3. The biological oxygen demand was reduced from $1400 \mathrm{mg} / \mathrm{l}$ to $400 \mathrm{mg} / \mathrm{l}$ and the chemical oxygen demand was reduced from $4200 \mathrm{mg} / \mathrm{l}$ to $500 \mathrm{mg} / \mathrm{l}$. The Psuedomonas putida has the capacity to reduce chemical oxygen demand upto 70\% [58]. The BOD and COD reduction occurs during the logarithmic growth phase. BOD and COD reduction was maximum during the maximum

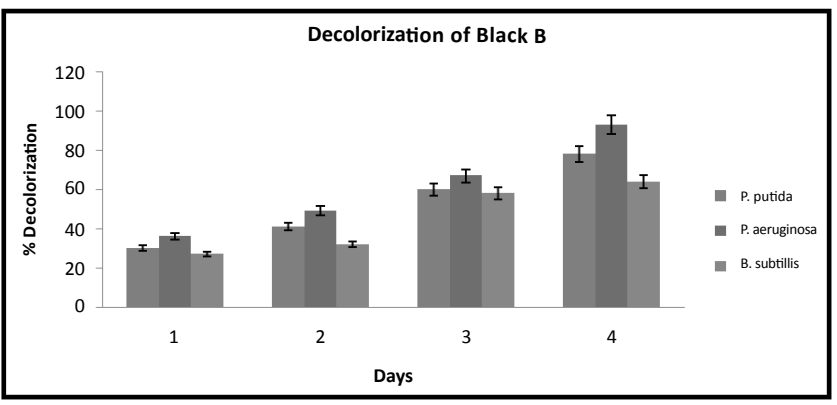

Figure 4: Decolorization of Black B.

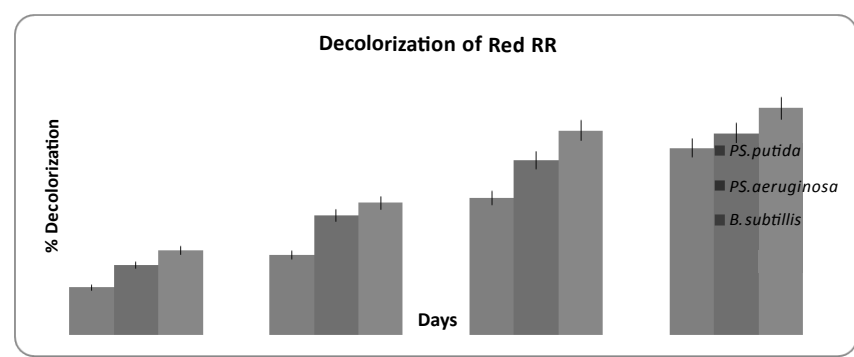

Figure 5: Decolorization of Red RR.

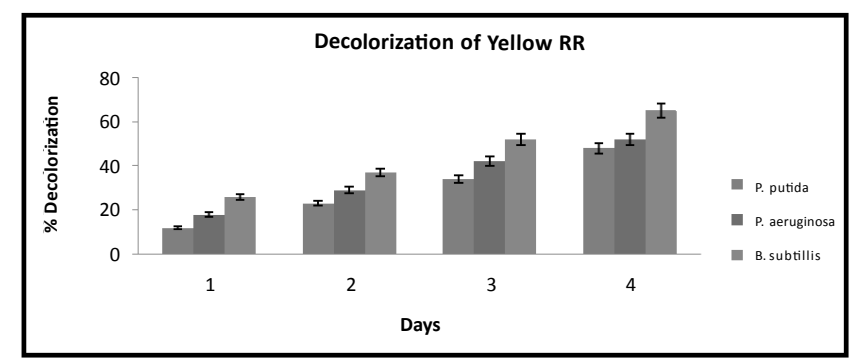

Figure 6: Decolorization of Yellow RR. 


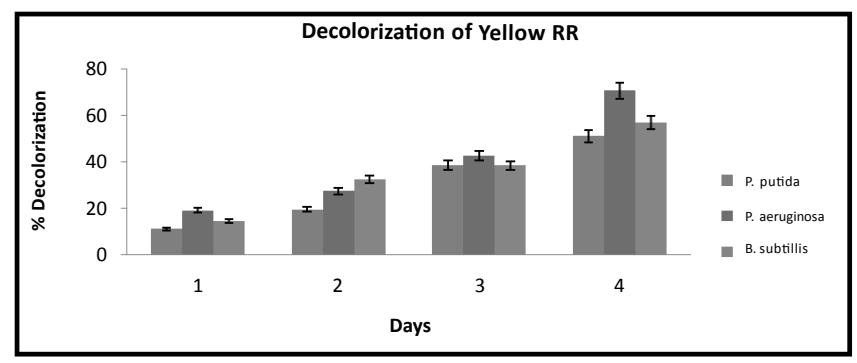

Figure 7: Decolorization of Navy Blue.

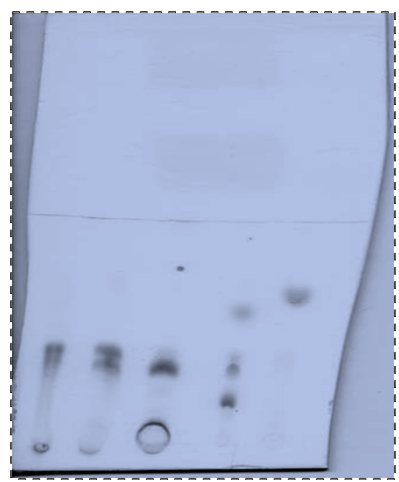

Figure 8: Result Analysis by Thin Layer Chromatography

stationary growth phase [59]. The bacterial isolates like Acinetobacter sp., Bacillus sp. and Legionella sp. had potential for color removal and strains of Acinetobacter sp., Bacillus sp. and Pseudomonas sp. had potential for COD removal activities [54].

TLC and FTIR result of biodegradable product: The dye decolorization study of bacterial isolate was further supported by TLC analysis (Figure 8). When the dye chromatogram was observed in UV light, the brown spot with Rf value $0.22,0.35,0.35,0.26$ and 0.35 were observed while no such band were observed for spots of dye and Uninoculated medium, strongly indicating that decolorization was only due to dye degradation.

Fourier Transform Infrared Spectroscopy (FTIR) analyses were done for the control and the decolorized sample (Figures 1 and 2) the results of which showed various peaks. The FTIR spectrum of control mixed dye displayed a peak at $3,415 \mathrm{~cm}^{-1}$ for the intermolecular hydrogen bonding aromatic - $\mathrm{OH}$ and $\mathrm{O}-\mathrm{H}$ stretching; a peak at 2,929 $\mathrm{cm}^{-1}$ for C-H stretching of alkyl acetals and a peak at $2,445 \mathrm{~cm}^{-1}$ for $\mathrm{N}-\mathrm{H}$ stretching of amines; a peak at $1,618 \mathrm{~cm}^{-1}$ for $\mathrm{C}=\mathrm{N}$ stretching of azo group; a peak at $1,047 \mathrm{~cm}^{-1}$ for $\mathrm{S}=\mathrm{O}$ stretching of sulfonic acid; a peak at 892 and $665 \mathrm{~cm}^{-1}$ for aromatic nature and C-C1 stretching respectively. The degradation metabolites of mixed dye showed a peak at $3,227 \mathrm{~cm}^{-1}$ for secondary amides, $1,654 \mathrm{~cm}^{-1}$ for $\mathrm{C}=\mathrm{C}$ and $\mathrm{C}=\mathrm{N}$ stretching and presence of amide bond, a peak at $1,404 \mathrm{~cm}^{-1}$ for $\mathrm{O}=\mathrm{H}$ stretching and a peak at $620 \mathrm{~cm}^{-1}$ for $\mathrm{C}-\mathrm{C} 1$ stretching indicating the presence of alkyl chloride. It indicated formation of nitrosamines, alkyl chloride, secondary and tertiary amides after decolorization. The chemical structure of the dye greatly influenced their decolorization rates and the decolorization efficiency is limited to several azo dye structures. Dye with simple structures and low molecular weights usually exhibited higher rates of color removal, whereas color removal was more difficult with highly substituted, high molecular weight dyes. For this reason, RY107 and RR198 which are both monoazo showed a short decolorization time (12 and $10 \mathrm{~h}$, respectively), while the highly substituted diazo RB5 and the triazo DB71 showed longer decolorization time ( 24 and $48 \mathrm{~h}$, respectively). It has been reported that the turnover rate of monoazo dyes increased with increasing dye concentration, whereas the turnover rate of the diazo and triazo dyes remained constant as the dye concentration increased [60].

\section{Conclusion}

Color removal of industrial effluent has been a major concern in waste water treatment, especially for the waste water that originates from textile and dye stuff plant with a continuous discharge of great quantity of remaining dyes to the environment. The efficient treatment of the effluent is an eco- friendly method for the treatment of textile effluent. Application of traditional waste water treatment requires enormous cost and continuous input of chemicals which becomes uneconomical and causes further environmental damage. Hence, economical and eco-friendly techniques using bacteria can be applied for fine tuning of waste water treatment. Biotreatment offers easy, cheaper and effective alternative for color removal of textile dyes. Thus, by this present study we strongly concluded that the bacterial isolates like Bacillus subtilis, Pseudomonas aeruginosa, and Psuedomonas putida were used as a good microbial source for waste water treatment, specifically in biological degradation of textile dye effluent.

\section{Acknowledgement}

Authors are highly grateful to the management of Enviro Technology Limited, Ankleshwar, Gujarat, India for allowing us to carry out such a noble work for the sustainable environment.

\section{References}

1. Appasamy PP (2000) Madras School of Economics 14: 76.

2. Bhagirath B, Reddy VR (2002) Environment and Accountability. Economic and Political Weekly 37.

3. Juwarkar A, Padole LM, Oke BH (1997) HRTS effluent treatment. The Indian Textile Journal 14

4. Gopal B (1994) Conservation of inland waters in India, An overview. Verh Internat Verein Limnol 25: 2494.

5. CF Gurnham (1965) Industrial waste control academic press, New York

6. Sharma KP, Sharma K, Bhardwaj SM, Chaturvedi RK, Sharma S (1999) Environmental Impact Assessment of textile printing industries in sanganer, jaipur: a case study. J Indian Bot Soc 78: 71.

7. Hamza A, Hamoda MF (1965) Multiprocessing treatment of textile wastewater In pro 35 produce Indust Waste Conf., Lafayette, Ind.

8. Groves GR, Buckley CA (1980) Treatment of textile effluents by membrane separation processes. In Proc. $7^{\text {th }}$ Int. Symp. on Fresh Water from the Sea, ed. Eur. Fed. Chem. Eng 2: 249-257.

9. McKay G (1980) Color removal by adsorption. Am Dyestuff rep 69: 38-45.

10. GR Brower, GD Reed (1987) Economic pretreatment for color removal from textile dye wastes. In pro. 41 Purdue Industry Waste Conf. Lafayette, Ind.

11. Arslan-Alaton I (2007) Degradation of a commercial textile biocide with advanced oxidation processes and ozone. J Environ Manage 82: 145-154

12. Alinsafi A, Evenou F, Abdulkarim EM, Pons MN, Zahraa O, et al. (2007) Treatment of textile industry wastewater by supported photocatalysis. Dyes Pigm 74: 439-445

13. Behnajady MA, Modirshahla N, Shokri M (2004) Photodestruction of Acid Orange 7 (AO7) in aqueous solutions by $\mathrm{UV} / \mathrm{H}_{2} \mathrm{O}_{2}$ : influence of operational parameters. Chemosphere 55: 129-134.

14. Brosillon S, Djelal H, Merienne N, Amrane A (2008) Innovative integrated process for the treatment of azo dyes: coupling of photocatalysis and biological treatment. Desalination 222: 331-339.

15. El-Gohary FA, Badawy MI, El-Khateeb MA, El-Kalliny AS (2009) Integrated 
Citation: Shah MP (2014) Biodegradation of Azo Dyes by Three Isolated Bacterial Strains: An Environmental Bioremedial Approach. J Microbial Biochem Technol S3: 007. doi:10.4172/1948-5948.S3-007

Page 5 of 5

treatment of olive mill wastewater (OMW) by the combination of Fenton's reaction and anaerobic treatment. J Hazard Mater 162: 1536-1541.

16. Hao J, Song F, Huang F, Yang C, Zhang Z, et al. (2007) Production of laccase by a newly isolated deuteromycete fungus Pestalotiopsis $\mathrm{sp}$. and its decolorization of azo dye. J Ind Microbiol Biotechnol 34: 233-240.

17. Lu X, Yang B, Chen J, Sun R (2009) Treatment of wastewater containing azo dye reactive brilliant red $X-3 B$ using sequential ozonation and upflow biological aerated filter process. J Hazard Mat 161: 241-245.

18. Moustafa ME (2005) Synthesis and structural and biological activity studies on some lanthanide chelates with O- and N-containing ligands. Spectr Lett 38: 23-34

19. Pearce CI, Lloyd JR, Guthrie JT (2003) The removal of colour from textile wastewater using whole bacterial cells: a review. Dyes Pigm 58: 179-196

20. Saxe JP, Lubenow BL, Chiu PC, Huang CP, Cha DK (2006) Enhanced biodegradation of azo dyes using an integrated elemental iron-activated sludge system effects of physical-chemical parameters. Wat Env Res 78: 26-30

21. Wang A, Qu J, Liu H, Ge J (2004) Degradation of azo dye Acid Red 14 in aqueous solution by electrokinetic and electrooxidation process. Chemosphere 55: $1189-1196$

22. Dubrow SF, Boardman GD, Michelsen DL (1996) Chemical pretreatment and aerobic-anaerobic degradation of textile dye wastewater. In: Reife A, Freeman HS (eds) Environmental chemistry of dyes and pigments. Wiley, New York

23. Khalid A, Arshad M, Crowley DE (2009) Biodegradation potential of pure and mixed bacterial cultures for removal of 4-nitroaniline from textile dye wastewater. Water Res 43: 1110-1116.

24. Paździor K, Klepacz-Smółka A, Ledakowicz S, Sójka-Ledakowicz J, Mrozińska $Z$, et al. (2009) Integration of nanofiltration and biological degradation of textile wastewater containing azo dye. Chemosphere 75: 250-255.

25. Worch E, Grischek T, Bomick H, Eppinger P (2002) Laboratory tests for simulating attenuation processes of aromatic amines in riverbank filtration. $J$ Hydrol 266: 259-268

26. Cartwright RA (1983) Historical and modern epidemiological studies on populations exposed to $\mathrm{N}$-substituted aryl compounds. Environ Health Perspect 49: 13-19.

27. Chung KT, Cerniglia CE (1992) Mutagenicity of azo dyes: structure-activity relationships. Mutat Res 277: 201-220.

28. Makinen PM, Theno TJ, Ferguson JF, Ongerth JE, Puhakka JA (1993) Chlorophenol toxicity removal and monitoring in aerobic treatment: recovery from process upsets. Env Sci Technol 27: 1434-1439.

29. Miller JA, Miller EC (1983) Some historical aspects of $\mathrm{N}$-aryl carcinogens and their metabolic activation. Environ Health Perspect 49: 3-12

30. Oztürk A, Abdullah MI (2006) Toxicological effect of indole and its azo dye derivatives on some microorganisms under aerobic conditions. Sci Total Environ 358: 137-142.

31. Pinheiro HM, Touraud E, Thomas O (2004) Aromatic amines from azo dye reduction: status review with emphasis on direct UV spectrophotometric detection in textile industry wastewaters. Dyes Pigm 61: 121-139.

32. Saupe A (1999) High-rate biodegradation of 3- and 4-nitroaniline. Chemosphere 39: $2325-2346$

33. Weisburger JH (2002) Comments on the history and importance of aromatic and heterocyclic amines in public health. Mutat Res 506-507: 9-20.

34. Carliell CM, Barclay SJ, Naidoo N (1994) Anaerobic decolorisation of reactive dyes in conventional sewage treatment processes. Wat SA 20: 341-344

35. Manu B, Chauhari S (2003) Decolorization of indigo and azo dyes in semicontinuous reactors with long hydraulic retention time. Process Biochem 38: $1213-1221$

36. Boon N, Goris J, De Vos P, Verstraete W, Top EM (2000) Bioaugmentation of activated sludge by an indigenous 3-chloroaniline-degrading Comamonas testosteroni strain, I2gfp. Appl Environ Microbiol 66: 2906-2913.

37. McClure NC, Fry JC, Weightman AJ (1991) Survival and catabolic activity of natural and genetically engineered bacteria in a laboratory-scale activatedsludge unit. Appl Environ Microbiol 57: 366-373.

38. Rittman BE, Whiteman R (1994) Bioaugmentation: a coming of age. Biotechnol 1: $12-16$.
39. van Limbergen HV, Top EM, Verstrate W (1998) Bioaugmentation in activated sludge: current features and future perspectives. Appl Microbiol Biotechnol 50: 16-23.

40. Franciscon E, Zille A, Garboggini FF (2009) Microaerophilic-aerobic sequential decolourization/biodegradation of textile azo dyes by a facultative Klebsiella sp. strain VN-31. Process Biochem 44: 446-452.

41. Khalid A, Arshad M, Crowley DE (2008) Accelerated decolorization of structurally different azo dyes by newly isolated bacterial strains. Appl Microbiol Biotechnol 78: 361-369.

42. Khalid A, Arshad M, Crowley DE (2008) Decolorization of azo dyes by Shewanella sp. under saline conditions. Appl Microbiol Biotechnol 79: 1053 1059

43. Bafana A Chakrabarti T, Muthal P Kanade G (2009) Detoxification of benzidine-based azo dye by $\mathrm{E}$. gallinarum: time-course study. Ecotoxico Environ Saf 72: 960-964.

44. Jadhav JP, Govindwar SP (2006) Biotransformation of malachite green by Saccharomyces cerevisiae MTCC 463. Yeast 23: 315-323.

45. Khehra MS, Saini HS, Sharma DK, Chadha BS, Chimni SS (2005) Comparative studies on potential of consortium and constituent pure bacterial isolates to decolorize azo dyes. Water Res 39: 5135-5141.

46. Khehra MS, Saini HS, Sharma DK, Chadhaa BS, Chimni SS (2005) Decolorization of various azo dyes by bacterial consortia. Dyes Pigm 67: 55-61.

47. Kornillowicz-Kowalska TK, Wrzosek M, Ginalska G, Iglik H, Bancerz R (2006) Identification and application of a new fungal strain Bjerkandera audusta R59 in decolorization of daunomycin wastes. Enz Microbial Technol 38: 583-590.

48. Pandey A, Singh $P$, lyengar $L$ (2007) Bacterial decolorization and degradation of azo dyes. Int Biodeter Biodegr 59: 73-84.

49. Busse HJ, Kämpfer P, Denner EB (1999) Chemotaxonomic characterisation of Sphingomonas. J Ind Microbiol Biotechnol 23: 242-251.

50. White DC, Sutton SD, Ringelberg DB (1996) The genus Sphingomonas: physiology and ecology. Curr Opin Biotechnol 7: 301-306.

51. Jin R, Zhou J, Zhang A, Wang J (2008) Bioaugmentation of the decolorization rate of acid red $G R$ by genetically engineered microorganism Escherichia coli JM109 (pGEX-AZR). World J Microbiol Biotechnol 24: 23-29.

52. Limbergen HV, Top EM, Verstrate W (1998) Bioaugmentation in activated sludge: current features and future perspectives. Appl Microbiol Biotechnol 50: 16-23.

53. Dabert P, Delgenes JP, Moletta R, Godon JJ (2002) Contribution of molecular microbiology to the study in water pollution removal of microbial community dynamics. Rev Env Sci Biotechnol 1: 39-49.

54. Olukanni OD, Osuntoki AA, Gbenle GD (2005) Textile effluent biodegradation potentials of textile effluent-adopted and non-adopted bacteria. Applied Environmental Microbiology: 837- 844

55. Ajibola VO, Oniye SJ, Odeh CE, Olugbodi T, Umeh UG (2005) Biodegradation of Indigo containing texile effluent using some strains of bacteria. Journal of Applied Sciences. 5: 853-855

56. Min-Ho Joe, Sang-Young Lim, Dong-Ho Kim and In-Soo Lee (2008) Decolourization of reactive dyes by Clostridium bifermentans SL186 isolated from contaminated soil. World Journal of Microbiology and Biotechnology. 24 117-121.

57. Bragger JL, Lloyd AW, Soozandehfar SH, Bloomfield, Marriot C, Martin GP (1997) Investigation on the azo reducing activity of a common colonic microorganisms. International Journal of Pharmacy. 157: 61-71.

58. Chen Shiong Chong, Zaharah Ibrahim, Madihah Md Salleh, Noor Aini Abdu Rashid, Adibah Yahya and Wui Jin Wong (2006) Decolorization of azo dye Direct Blue-15 using batch culture of Klebsiella sp. Petroleum and Natura Resource Process: 595-600.

59. Hu TL (1998) Degradation of azo dye RP2B by Pseudomonas luteola. Water Science and Technology 38: 299-306.

60. Elisangela F, Andrea Z, Fabio DG, de Menezes RC, Reginaa DL, et al (2009) Biodegradation of textile azo dyes by a facultative Staphylococcus arlettae strain VN-11 using a sequential microaerophilic/aerobic process. Int Biodeter Biodegr 63: 280-288 